To the Editors:

\title{
Prevalence of chronic kidney disease in two tertiary care hospitals: high proportion of cases with uncertain aetiology
}

The prevalence of chronic kidney disease (CKD) is rising globally, and is attributed to the epidemic of type 2 diabetes mellitus [1]. This trend in developing countries appears to be due to chronic glomerulonephritis and diabetes, both contributing significantly to increasing endstage renal disease [2]. In Sri Lanka, a systematic assessment on CKD is lacking, although the available literature points to a rising trend in hospital admissions and deaths due to CKD [3]. This study attempts to document some features of CKD and describe cases with an uncertain aetiology observed at two teaching hospitals in Kandy and Anuradhapura between 2000 and 2002.

We conducted a retrospective, descriptive study of CKD patients ( $\mathrm{n}=492)$, using information collected from clinic records (Nephrology Unit, Kandy, NUK =146, Renal Clinic, Anuradhapura, RCA = 246). When further information was required, verbal consent was obtained by the research officer who administered the questionnaire. The diagnosis of CKD was based on KDQOI of National Kidney Foundation of USA criteria [4]. The study commenced at NUK and was then extended to RCA, since a high number of CKD patients from the North Central Province (NCP) was noted (table 1).

The cohort was observed to be in different stages of CKD varying from mild, moderate, severe to end-stage (table 2). The majority (61\%) of patients at NUK were in late stages (severe and end-stage) of the disease whilst most $(79 \%)$ at RCA were in early stages. A fair number of patients from RCA ( $9 \%$ ) were from Medawachchiya. The key finding in this study was that the cause of CKD was not identifiable in the majority of patients in both clinics $(\mathrm{NUK}=54 \%$, RCA $82 \%$ ). These patients were categorized into a separate group as "uncertain aetiology" (UA). In contrast, the world literature shows that the prevalence of UA among CKD patients less than 65 years old varies from $6.2-14.7 \%[5]$.

Table 1. Demographic characteristics of patients at Nephrology Unit, Kandy and Renal Clinic, Anuradhapura (2000-2002)

\begin{tabular}{|c|c|c|c|}
\hline & & $\begin{array}{l}\text { Nephrology Unit, } \\
\text { Kandy (NUK) }\end{array}$ & $\begin{array}{l}\text { Renal Clinic, } \\
\text { Anuradhapura (RCA) }\end{array}$ \\
\hline & & $\% \quad(n=146)$ & $\%(n=246)$ \\
\hline \multirow[t]{2}{*}{ Sex } & Male & $66(97)$ & $79(195)$ \\
\hline & Female & $34(49)$ & $21(51)$ \\
\hline \multirow[t]{4}{*}{ Age (yrs) } & $12-18^{*}$ & $14(21)$ & $10(24)$ \\
\hline & $19-39$ & $27(39)$ & $36(88)$ \\
\hline & $40-64$ & $44(65)$ & $46(114)$ \\
\hline & $>64$ & $14(21)$ & $8(20)$ \\
\hline \multirow[t]{6}{*}{ Province } & NP & - & $34(14)$ \\
\hline & $\mathrm{NCP}$ & $21(32)$ & $86(212)$ \\
\hline & $\mathrm{CP}$ & $35(51)$ & - \\
\hline & $\mathrm{W}$ & $17(25)$ & - \\
\hline & SB & $11(16)$ & - \\
\hline & others & $22(16)$ & - \\
\hline Occupation & Farmer & $44(64)$ & $70(173)$ \\
\hline
\end{tabular}

NP- Northern Province (Vavuniya); NCP- North Central Province;

CP - Central Province; WP - Wayamba Province; SB - Sabaragamuwa Province

*The study population was from adult clinics and patients were $>12$ years old. 
CKD of UA in our study appeared to affect young males, from low socio-economic, paddy farming communities (NUK $=90 \%, \mathrm{RCA}=94.5 \%$ ). Patients with mild to moderate stages of the disease were typically without uraemia and had only vague symptoms of backache and dysuria. Mild proteinuria ( $<1$ gram/24 hours) and bilateral echogenic small kidneys were typical findings, and the mean bipolar length of the kidneys was $8.3 \mathrm{~cm} \pm 1.4(\mathrm{n}=122)$. The urine full report did not show an active deposit and hypertension was not a common feature. Those who were in late stages of CKD and were hypertensive $(\mathrm{NUK}=40 \%$ and $\mathrm{RCA}=14 \%)$ did not have ECG evidence of left ventricular hypertrophy, indicating that raised blood pressure was probably due to the disease, rather than being the cause of CKD.

Reports on CKD of UA from other countries are few, and this could be because of poor documentation. In the Balkan region CKD of UA has been reported among low socio-economic groups in well defined geographical locations. The prevalence of Balkan endemic nephropathy (BEN) varies from 0.5 to $4.4 \%$ in the affected regions along the river Danube [6]. The disease characteristics of BEN appears to be different from the CKD of UA prevalent in the NCP of Sri Lanka; BEN affects more females and is associated with uroepitheleal tumours [6]. A recent study suggests a role for environmental factors in CKD of UA here [7].

\section{Table 2. Clinical characteristics and geographical distribution of patients with CKD at NUK and RCA}

\begin{tabular}{lcc}
\hline & $\begin{array}{l}\text { Nephrology Unit, } \\
\text { Kandy (NUK) }\end{array}$ & $\begin{array}{c}\text { Renal Clinic, } \\
\text { Anuradhapura (RCA) }\end{array}$ \\
\cline { 2 - 3 }$\%(n=146)$ & $\%(n=246)$ \\
\hline Estimated creatinine clearance $[8]$ & & \\
ml/min & & \\
$>60$ (mild) & $17(25)$ & $21(51)$ \\
$60-30$ (moderate) & $22(32)$ & $58(143)$ \\
$29-15$ (severe) & $39(57)$ & $17(41)$ \\
$<15$ (late stage) & & \\
Associations/aetiology & $22(32)$ & $4(11)$ \\
Diabetes & & $2(6)$ \\
Hypertension (on treatment) & $5(8)$ & $14(34)$ \\
Uncertain aetiology & $40(58)$ & $82(201)$ \\
Other & $54(79)$ & $15(37)$ \\
Geographical distribution (province) & $39(57)$ & \\
NP & & $11(22)$ \\
NCP & & $89(179)$ \\
CP & - & - \\
WP & $41(32)$ & - \\
SB & $16(13)$ & - \\
Others & $20(16)$ & - \\
\hline & $5(4)$ & \\
\hline
\end{tabular}

(Note: CKD is defined by the criteria of Kidney Disease Quality Outcome Initiative (KDQOI) of the National Kidney Foundation, USA [4] where a structural and/or functional deterioration (GFR $<60 \mathrm{ml} / \mathrm{min}$ ) of the kidney lasting for $>3$ months is/are considered as evidence of CKD. The GFR $>60 \mathrm{ml} / \mathrm{min}$ category therefore had evidence of structural damage (urine protein, ultrasonography changes). 


\section{References}

1. Nahas AMEI, Belle AK. Chronic kidney disease: the global challenge. The Lancet, 2005; 365: 331-40.

2. Codreanu I, Perico N, Sharma SK, Schieppati A, Remuzzi G. Prevention programmes of progressive renal disease in developing nations. Nephrology 2006; 11: 321-28

3. Abeysekera DTDJ, Kaiyoom SAA, Dissanayake SU. Place of peritoneal dialysis in the management of renal failure patients admitted to General Hospital Kandy. Kandy Society of Medicine 18th Annual Academic Conference 1996: 19.

4. National Kidney Foundation: K/DOQI Clinical practice guidelines for chronic kidney disease: evaluation, classification and stratification. American Journal of Kidney Disease 2002; 39: S1-S266 (Supplement).
5. Wing AJ. Causes of end-stage renal failure. In: Davison MA, Cameron JS, Grünfeld JP, Ponticelli C, Ritz E, Winearls EG, eds. The Oxford Textbook of Clinical Nephrology 1st edition Oxford University Press, 1992; 2: 1227-35.

6. Ceovic S, Hrabar A, Saric M. Epidemiology of Balkan endemic nephropathy. Food and Chemical Toxicology 1992; 30: 183.

7. Wanigasuriya KP, Peiris-John RJ, Wickremasinghe R, Hittarage A. Chronic renal failure in North Central Province of Sri Lanka: an environmentally induced disease. Transactions of the Royal Society of Tropical Medicine and Hygiene 2007; 101(10): 1013-7.

8. Levey AS, Bosch JP, Lewis JB, Greene T, Rogers N, Roth D. A more accurate method to estimate glomerular filtration rate from serum creatinine: a new prediction equation. Annals of Internal Medicine 1999; 130: 461-70.

\section{T N C Athuraliya ${ }^{1}$, D T D J Abeysekera 2 , P H Amerasinghe ${ }^{3}$, P V R Kumarasiri ${ }^{4}$ and V Dissanayake ${ }^{5}$}

${ }^{1}$ Departments of Pharmacology and ${ }^{4}$ Community Medicine, Faculty of Medicine, University of Peradeniya, ${ }^{2}$ Nephrology Unit, Teaching Hospital, Kandy, ${ }^{5}$ Teaching Hospital, Anuradhapura, Sri Lanka and ${ }^{3}$ International Water Management Institute, Hyderabad Office, Patancheru, India.

Correspondence: TNCA, e-mail: <nimmia@pdn.ac.lk>. Received 3 July 2008 and revised version accepted 8 November 2008. Competing interests: none declared. 